\title{
CUVÂNTUL ROSTIT DE ACTOR Idei care emoționează
}

\author{
DOI 10.46522/CT.2021.02.02
}

\section{Cătălina-Elena Mihăilă}

\begin{abstract}
The Word Spoken by the Actor. Ideas that Move

The word spoken by the actor on stage can be caught beyond the beauty, clarity, precision of the soundtrack. We thus discover its deepness, the essence of the logos that convey ideas and emotions. Therefore, it cuts the verbal instrument's thought and soul and forms a connection between the inner universes belonging to the artist and the spectator. We are talking about a word born from a necessity and which acquires the quality of being organic, invading the inside of the receiver.
\end{abstract}

\section{Keywords:}

phrase, logic, feeling, idea, emotion, inner laboratory

\section{Noțiuni introductive}

$\Gamma$ ot arsenalul de mijloace-arme de expresie se unesc într-un scop comun pentru a transmite, pentru a „,mișca“ spectatorul: „Spectacolul care coboară de pe scenă și pătrunde în lume. “1 Actorul este cel care se des-

1. Eusebiu Ștefănescu, Retorica limbajului scenic. Magul captiv, Prahova, Editura Antet, 2003, p. 13. 
prinde din această „lume“ tocmai pentru a o schimba, rezonând cu concepția potrivit căreia „,idealul suprem al omului să fie omul însuși, singura ființă creatoare de cultură, singura ființă capabilă să schimbe lumea, și, mai ales, să se schimbe pe sine însuși.““2

În definirea acestui spectacol care nu rămâne doar expunere a unei alte realități, ne vom îndrepta atenția asupra actorului, ființa umană care își dă întâlnire cu altă ființă umană pentru a ,o stârni“", pentru a-i transmite un mesaj. În împlinirea acestui scop, actorul apelează la suita sa de mijloace de expresie, realizând între acestea un echilibru și o armonie tocmai ca ideea, mesajul, emoția să treacă dincolo de rampă.

Sigur că, atunci când propunem transmiterea unui mesaj pe scenă, ne gândim inevitabil la unul dintre instrumentele cu care jonglează actorul în majoritatea spectacolelor de teatru: cuvântul. Vom privi acest mijloc de exprimare dincolo de partea lui sonoră care, prin înglobarea unor principii de tehnică a emisiei vocale, îi produce o anumită plăcere auditivă spectatorului.

Vom porni în căutarea și spre definirea cuvântului „rostit care bate aerul și pătrunde cald în sufletul care-1 primește.““3 Vom aborda cuvântul ca element exterior care trebuie să rezoneze cu ,,interiorul“ spectatorului pentru a putea comunica, pentru a putea transmite. Astfel, cuvântul rostit de actor pe scenă realizează conexiunea dintre „interiorul“ actorului și „interiorul“ spectatorului, îndreptându-ne atenția asupra acestui laborator de creație lăuntrică a artistului, necesar în emiterea unui logos care transmite dincolo de semnificația lui originară, dată doar de corpul sonor al acestuia.

Cuvântul rostit de actor nu este doar cuvântul scris care se decupează din cuvintele așternute de artistul dramaturg pe hârtie și devine parte a realității, ci înseamnă cuvântul care „Vorbește“ deopotrivă cu mintea și cu sufletul spectatorului. Pentru a rezona cu acest univers lăuntric al privitorului și al ascultătorului, interpretul apelează la interiorul său, filtrând

2. Henri Wald, Puterea vorbirii, București, Editura Științifică și Enciclopedică, 1981, p. 118.

3. Eusebiu Ștefănescu, Retorica limbajului scenic, ed. cit., p. 24. 
cuvântul prin prisma gândirii și a trăirii, căutând esența acestui interior bine mobilat și echilibrat. Cuvântul trebuie să se nască dintr-o necesitate, nevoie de a exprima un preaplin lăuntric și, astfel, să dețină un fundament stabil al sonorului emis.

Cuvântul scris este izvorul cuvântului rostit de actor pe scenă. Prin rostire, acest cuvânt capătă oralitate și devine prezent. În acest punct, spectatorul primește un stimul, dar nu i se transmite o idee sau o emoție. Această conexiune ideală între cele două entități care se întâlnesc trebuie să ajungă la nivel de empatie și sinergie prin intermediul gândului cuvântului și al sufletului cuvântului. În acest sens, cuvântul „nu se referă doar la ceea ce spunem, ci la cum spunem. Fără să mai amintim că vorbele trebuie să fie și interpretate, nu doar rostite. ${ }^{* 4}$

\section{2. În căutarea ideii}

„Prin definiție, cuvântul este un aspect al realității, este o forță eficace. Dar forța cuvântului nu este orientată doar spre real, ea este inevitabil și puterea asupra celorlalți, nu există Aletheia fără Peitho. Această a doua formă a puterii cuvântului este primejdioasă, deoarece ea poate fi iluzia realului.“5

Această putere contribuie la realizarea spectacolului ca iluzie a realității. Pentru a căpăta această influență, forță asupra spectatorului, actorul își asumă această nouă realitate care îi propunere o nouă identitate. Dincolo de costumul, machiajul, masca care vin în conturarea completă a acestei noi identități, mai exact, a personajului, actorul trebuie să își asume un text, o sumă de cuvinte care întruchipează idei și emoții cu scopul de a contamina spectatorul și cu intenția de a atinge catharsisul.

Artistul dramatic, acest „tehnician al logosului“" materie primă textul dramatic, sursă în conturarea personajului, în delimitarea și definirea situațiilor scenice, a relațiilor, a motivației scenice. Acesta are sarcina de a-și asuma un text care

4. Kevin Dutton, Arta manipulării, Editura Globo, București, 2019, p. 8.

5. Marcel Detienne, Stăpânitorii de adevăr în Grecia Antică, București, Editura Symposion, 1996, p. 142.

6.Eusebiu Ștefănescu, Retorica limbajului scenic, ed. cit., p. 27. 
nu îi aparține și căruia trebuie să îi dea valoare sub influența intenției. El trebuie să contopească în această intenție atât pe cea originară a creatorului prim, a dramaturgului, cât și pe cea a creatorului spectacolului, a regizorului.

Pentru a putea modela această materie primă, actorul trebuie să se apropie de ea, să o descifreze, să o cunoască, tinzând spre asumarea acesteia până într-acolo încât să-i aparțină. Cu scopul transmiterii unor idei, el trebuie să cunoască, să înțeleagă și să își asume aceste idei.

Descoperirea acestor idei trebuie să dobândească o anumită rezonanță pentru spectator: ,,artistul este o ființă înzestrată cu anumite calități, care prind puternică expresie în opera de artă constitutivă. Considerăm că intuitivitatea de care dă dovadă creatorul reprezintă inteligența artistică. Intuiția, deci cea care stăpânește pe creatorul autentic, este indispensabilă procesului creației, și, fără îndoială, exprimării artistice a conținutului. Alături de intuiție, fantezia constituie un alt element propriu creatorului. Considerăm că un arc în cercul însușirilor artistice, al structurii personalității creatoare, este inspirația produsă de o idee, de un sentiment, de un motiv muzical, pictural sau coregrafic, menit să fie continuu prezent și să frământe îndelung spiritualitatea autorului."7

Sigur că aceste trei calități esențiale îl definesc pe actor drept creator și nu executant. Textul dramatic reprezintă pentru acesta sursa fundamentală de inspirație, dar și un material căruia trebuie să îi confere unicitate dincolo de claritate, sinceritate, simplitate și frumusețe.

Aminteam mai sus de un raționament care îndrumă artistul dramatic spre concretizarea textului dramatic în idei. Așa cum fiecare actor are propriul laborator de interpretare a unei alte identități, tot așa întâlnirea, apropierea, abordarea și asumarea textului diferă de la artist la artist. $\mathrm{Cu}$ toate că acest text va căpăta formă, esență, consistență prin trecerea prin filtrele interioare ale structurii fiecărui creator, nu trebuie uitată parcurgerea unor etape, a unui itinerariu care va conduce spre adevărata destinație.

7. Ion Toboșaru, Principii generale de estetică, Cluj-Napoca, Editura Dacia, 1978, pp. 209-210. 
Practic, acest algoritm este unul firesc atunci când vine vorba de comunicarea cotidiană. Ceea ce ghidează această comunicare uzuală este scopul, mai exact, intenția. Individul știe ce vrea să obțină și nu își pune problema, de exemplu, a accentului în frază. Problema pe care o întâmpină actorul este legată de faptul că ceea ce urmează să rostească nu îi aparține, fapt pentru care vom aduce în discuție, în vederea obținerii acestui cuvânt complet care transmite, asumarea textului, asumarea unei alte gândiri și, totodată, asumarea unei trăiri. Acest cumul de abordări și asumări ține, în cele din urmă, de asumarea unei alte identități.

Până la a deduce intenția generatoare de idee și emoție, actorul intră în contact cu textul dramaturgului, un ansamblu de cuvinte scrise care, în momentul de referință, sunt elemente ce aparțin literaturii: „Literatura este arta cuvântului. Cuvântul, în literatură, exprimă plastic și sugestiv, cognitiv și emoțional ideea creatorului, idee care devine artistică în structura operei, unitate a elementelor intuitive, senzoriale și intelective.“8 Iată că această definiție ne luminează calea spre cuvântul care urmează să capete vitalitate: o formă plastică a cuvântului capabil să sugereze, să trimită un stimul spre rațiune și să emoționeze. De asemenea, tot acest cuvânt este „1̂ncărcat de energia originară“9 și deține „consistența cuvântului scris care îi conferă perenitate. " ${ }^{10}$ Actorul trebuie să ia în calcul acea energie pe care o primește cuvântul de la creatorul său cel dintâi. Totodată, această apropiere față de cuvântul scris nu vine doar din dorința de a desluși forma în care trebuie tratat cuvântul pentru a transmite idei sau emoții, ci și din necesitatea irevocabilă a înțelegerii textului nu doar ca un tot unitar, ci și ca unul fragmentat.

$\mathrm{Cu}$ alte cuvinte, dramaturgul pleacă de la idei, emoții pe care le întruchipează în cuvinte ce compun imagini artistice, iar actorul pornește de la cuvinte spre a desluși ideea, emoția originară. Sigur că un text dramatic trebuie să se bucure de darul oralității. În caz contrar, efectul rostirii riscă să nu fie cel

8. Ibidem, p. 208.

9. Eusebiu Ștefănescu, Retorica limbajului scenic, ed. cit., p. 4.

10. Ibidem. 
dorit: ,,scriitorul care-i altceva decât un imitator verbal obligă implicit pe cetitor să se cerceteze pentru a-și evalua capacitatea de înțelegere față de materia și forma scrierii... Fiindcă un asemenea scriitor a plecat doar de la o experiență proprie neverbală, și de acolo a ajuns la cuvinte, iar cetitorul trebuie să facă același drum în direcția opusă: de la cuvinte la un cuprins de cunoștințe neverbale, pe care trebuie să-l creeze el, cetitorul, urmând și rezistând sugestiilor cetitorului.“11

Apropierea de textul dramatic, acest nou început pentru creatorul dramatic, debutează cu lecturi repetate care să prilejuiască descoperirea sensului și conținutului originar al fiecărui cuvânt. Vasile Moisescu introduce chiar termenul de „lectură artistică"12 și propune un traseu minuțios în descoperirea ideilor. El invită artistul, în primă instanță, la o documentare serioasă asupra ,autorului, a vieții lui, a operei, a stilului și a personalității.“13 Așadar, actorul descoperă o nouă entitate și face un studiu care să îl ajute să înțeleagă mai profund textul și ceea ce își propune scriitorul să transmită prin opera sa. Aceasta poate fi notată drept o primă etapă a algoritmului de descifrare a textului.

O a doua etapă definitorie în forjarea textului este frazarea, „o muncă de însușire a textului.“" ${ }^{414}$ Textul va fi delimitat în fraze deținătoare de idei. Marea provocare a frazării unui text izvorăște din faptul că acesta poate fi modelat, colorat, nuanțat în diferite moduri. Definitorii în descoperirea unei frazări „corecte“ sunt elementele ce definesc contextul: situația, relația și motivația. Aceste elemente-cheie vor încununa astfel un alt punct decisiv în frazare: analiza gramaticală, „,el mai științific procedeu de cercetare a ideilor și formulării lor în fraze." ${ }^{15}$

Sigur că fiecare cuvânt are importanța lui în fiecare frază și că deține o funcție gramaticală. Pentru evitarea unei

11. Paul Zarifopol, Pentru arta literară I, București, Editura Minerva, 1971, p. 82.

12. Vasile Moisescu, Lectura artistică și recitarea, București, Editura Comitetul de stat pentru cultură și artă, 1967, p. 9.

13. Ibidem, p. 11.

14. Ibidem.

15. Ibidem, p. 13. 
frazări albe, care să nu surprindă nicio nuanță, sau pentru a îndrepta atenția spre detalii neimportante, actorul trebuie să stabilească în fiecare frază accentul logic care „determină înțelegerea exactă a textului și stabilește cu precizie intențiile artistice. ${ }^{16}$ Acest accent logic luminează aprofundarea textului de către artistul dramatic, începe să definească idei și presupune sublinierea unui cuvânt, a unei sintagme sau a unei propoziții. Această logică a exprimării se deprinde prin exercițiu și trebuie să ajungă la nivelul în care să nu dezechilibreze fraza și conținutul acesteia. Există și la nivel de cuvânt un accent tonic, sublinierea unei anumite silabe care poate duce la accidente precum confuzia unui înțeles sau rostirea unor cuvinte străine limbii române.

Un rol esențial în definitivarea și clasificarea frazelor îl dețin semnele de punctuație. Alături de cuvântul scris, actorul ia la cunoștință punctuația scrisă, căreia trebuie să îi cunoască semnele și, mai ales, rolul acestora. Așa cum există neconcordanțe între ortografie și ortoepie, așa se întâlnește o neconcordanță între punctuația scrisă și cea orală. „Punctuația orală se adresează urechii spectatorului și nu ochiului cititorului, ca pronunția scrisă. ${ }^{117}$ Cel mai relevant exemplu este cel întâlnit în cazul interpretării unei creații lirice atunci când există o virgulă în interiorul frazei care, respectată prin scurta pauză specifică semnului, poate duce la fragmentarea unei idei. Există o metodă agreată sau nu, în funcție de algoritmul fiecărui creator, de a transcrie textul fără niciun semn de punctuație tocmai pentru a stabili semnele de punctuație necesare în transmiterea mesajului și în împlinirea intențiilor artistice.

Trecerea de la o frază, care va deveni idee, la alta, se realizează prin intermediul unei pauze logice care vine tot pe firul unei exprimări logice. Nu trebuie asemănată cu cea psihologică, care nu are rădăcini în raționamentul logic, ci are valențe de coloristică afectivă. Nu are legătură cu tăcerea de pe scenă care transmite. Ea vine doar să delimiteze frazele și ideile între ele.

16. Valeria Covătariu, Cuvinte despre cuvânt, Târgu Mureș, Casa de Editură Mureș, 1996, p. 23.

17. Vasile Moisescu, Lectura artistică și recitarea, ed. cit., p. 29. 
Acest demers care pleacă de la cuvânt și ajunge la distingerea unor fraze care devin idei nu este unul în care se urmărește doar forma pe care trebuie să o capete textul în vederea comunicării cu sala. El invită artistul la o înțelegere amănunțită și profundă a conținutului și a ideilor care constituie un mesaj. Odată ce artistul va înțelege ce urmează să transmită prin intermediul acelor cuvinte, el nu își va mai pune problema cum să rostească. Acest cum va veni tocmai din conținutul descoperit și va defini forma.

De asemenea, în urma acestui laborator de creație al cuvântului în vederea făuririi de idei, cuvântul se desprinde din literatură și capătă oralitate, „,condiția originară a poeziei, dar și a teatrului, dacă plecăm de la ideea că teatrul s-a născut tot din dorința permanentă de a intra în contact cu divinitatea, de a intra în rezonanță cu ritmurile cosmice“"18, actorul fiind privit precum ,acel vis al omului de a se conecta spiritual la energiile cosmice. “19 De asemenea, „prin oralitate, scrierea se convertește în convenție scenică, capătă conotații și devine contemporană cu orice prezent. “20

\section{Gândul cuvântului}

Traseul mai sus expus a coordonat procesul de delimitare a textului în fraze. Prin intermediul oralității, se produce un transfer al cuvântului scris în cel rostit și se face posibilă trecerea frazei în idee. „Rostul rostirii este să redreseze conotațiile culcate în text. “21 Acest transfer devine realizabil prin intermediul vorbirii, care „transformă informația naturală nu numai în cunoștințe, ci și în evaluări. Informația pe care o comunică vorbirea este nu numai intectuală, ci și valorificatoare, nu numai reflexivă, ci și apreciativă.“222

Vorbirea este cea care duce la emiterea și transmiterea ideilor. Pentru ca aceasta să transmită un stimul intelectual

18. Eusebiu Ștefănescu, Retorica limbajului scenic, ed. cit., p. 7.

19. Ibidem, p. 27.

20. Ibidem, p. 44.

21. Henri Wald, Puterea vorbirii, ed. cit., p. 15.

22. Ibidem, p. 7. 
către spectator, ea trebuie să transmită dincolo de cuvinte, actorul asumându-și întreg procesul de gândire care face posibilă, prin intermediul acesteia, exprimarea unor idei. Mai mult decât atât, „prin participarea nemijlocită la formarea și dezvoltarea noțiunilor, prin capacitatea ei de abstractizare și generalizare, vorbirea produce nu numai o cantitate mai mare de informație decât primește, ci creează o informație de o altă calitate și substanță: ideea. “23

Sigur că vorbirea este cea care materializează ideea. În spatele unei idei, stă un gând. Vorbirea dă expresie procesului de gândire. Gândind comunicarea dintre actor și spectator ca două lumi interioare care comunică, gândul actorului ajunge la gândul spectatorului prin idee. De aceea, se vehiculează noțiunea de gând viu, care presupune trecerea ideilor pe care actorul trebuie să le comunice prin filtrul propriei gândiri, asumându-și, pe lângă o nouă identitate, și o altă gândire. Dincolo de faptul că vorbirea dă sonoritate, prin idee, gândului, ,iluzia originii transcendente sau transcendentale a ideilor se risipește dacă se arată că vorbirea este nu numai principalul mijloc de comunicare, dar și principalul instrument de formare a gândurilor. ${ }^{\text {“24 }}$ Așadar, vorbirea produce ideile artistului, care devin „materia din care se construiesc gândurile“25 spectatorului. Putem privi întâlnirea acestor doi oameni din dorința de a vorbi și de a stârni gândirea: „Oamenii n-au început să vorbească pentru a gândi, ci pentru a comunica, dar vorbind, oamenii au început să gândească.“26 De altfel, a gândi înseamnă a mânui semnele limbii ${ }^{27}$. Pe de altă parte, gândirea ,apare ca o iluzie naivă, care se ivește în decursul operațiilor cu semne. ${ }^{\text {"28 }}$

\section{Ibidem.}

24. Henri Wald, Ideea vine vorbind, București, Editura Cartea Românească, 1983, p. 55.

25. Ibidem.

26. Ibidem, p. 102.

27. Emile Benveniste, Problèmes de linguistique générale, Paris, Éditions Gallimard, 1966, p. 74.

28. Henri Wald, Realitate și limbaj, București, Editura Academiei Republicii Socialiste, 1968, p. 8. 
Asemănând vorbirea cu jocul, ne apropiem de vorbirea pe care dorește să o dețină actorul: „,jocul este intențional, contrar spontaneității naturale, este organizat, deci antrientropic, social în opoziție cu individualitatea reacțiilor imediate, iterativ, spre deosebire de efemeritatea întâmplărilor. ${ }^{“ 29}$ Asupra aspectului iterativ, actorul trebuie să păstreze fix gândul viu de fiecare dată, tocmai ca ideea să fie una proaspătă și să dea iluzia că exact în momentul prezent ia naștere.

Revenim la perspectiva vorbirii care nu este doar un mijloc de exprimare a gândului, ci chiar un mijloc de dezvoltare a gândirii, susținând conceptul lui Henri Wald că „ideea vine vorbind“. Și în acest context, există un limbaj lăuntric al artistului care, prin exteriorizare, ajunge la spectator. Ideile transmise trebuie să devină așadar „principalul stimulent al gândirii și al dezvoltării ei““30 pentru spectator.

Această vorbire prin care se dezvoltă și se nasc alte idei prin intermediul cuvintelor și al semnificației acestora are un crucial aspect de continuitate. Putem discuta astfel de o vorbire în planul doi, o vorbire nerostită: ,a gândi în liniște nu înseamnă a nu vorbi, ci a nu rosti. “31 În completarea acestei idei, se ridică problema identificării unui spațiu și a unei durate a acestor idei tocmai din dorința omului de a le vizualiza. Cu siguranță, ,ideile nu se află nicăieri; ele sunt produse și reproduse mereu prin actul rostirii“ ${ }^{\prime 32}$ și „nu durează mai mult decât vorbele, ci cât rostirea lor. Durata ideilor este menținută de vorbirea interioară.“33

Această vorbire interioară este punct de referință deopotrivă pentru actor și spectator. În cazul inițiatorului comunicării, „,vorbirea lăuntrică ajunge să transforme o experiență originală într-o expresie inedită.“34 Totodată, această vorbire apare și sub numele de monolog interior și are o serie aspecte diferite de cele ale vorbirii propriu-zise.

\section{$\diamond$}

29. Henri Wald, Puterea vorbirii, ed. cit., p. 39.

30. Ibidem, p. 95.

31. Ibidem, p. 94.

32. Ibidem, p. 89.

33. Ibidem, p. 94.

34. Ibidem, p. 64. 
„Prin interiorizare, rostirea devine preponderent predicativă și polisemică, prescurtându-se și accelerându-și ritmul. Cine își vorbește sieși, poate să lase subiectul gramatical și logic subînțeles, important devine predicatul, sediul lingvistic al plusului de informație.““35 Astfel, capătă sens ideea de a gândi mai repede decât se poate verbaliza. Dacă în cazul actorului avem acest tip de vorbire nerostită ca un laborator de creație a ideii, pentru spectator acest proces lăuntric trebuie să tindă spre înțelegere ca „o formă de dialog; ea este față de enunțare ceea ce replica este față de replică într-un dialog. A pricepe înseamnă a opune vorbirii locutorului o contra-vorbire.“36

Sigur că o gândire clară va da naștere unei idei clare. Dincolo de această claritate, ideea trebuie să se bucure de simplitate, sinceritate, adevăr, firesc, dar nu de banal. „Banalizarea transformă, până la urmă, orice adevăr într-un truism, adică într-o cunoștință care nu încetează să fie adevărată, dar încetează să mai fie o informație.“37 Încununând calitățile enumerate, ,ideile pot pătrunde până la stabilitatea relativă a esențelor. ${ }^{\text {“38 }}$

\section{Sufletul cuvântului}

Putem considera că sunetul are un plus în pofida imaginii, deoarece imaginea poate fi descifrată tot prin intermediul vorbirii rostite sau lăuntrice. Pornim, așadar, de la premisa că doar sonorul cuvântului emoționează. Împlinind acest sunet, ,actorul devine cuvânt însuflețit și însuflețitor.“"39 Acest cuvânt-suflet este „cuvântul cu toată energia lui, cu toată puterea lui eficace." 40

Pentru a depăși conceptul descris anterior despre ideea care transmite, ne vom îndrepta atenția spre o altă unitate

35. Ibidem, p. 43.

36. Ibidem, p. 95.

37. Ibidem, pp. 8-9.

38. Ibidem, p. 52.

39. Eusebiu Ștefănescu, Retorica limbajului scenic, ed. cit., p. 23.

40. Ibidem, p. 15. 
lăuntrică a actorului care va ornamenta și va împlini cuvântul. Actorul trebuie să își ia în serios și rolul de a jongla cu emoția la nivel colectiv. Când spunem manipulare, ne întreptăm atenția spre persuasiune. El trebuie să convingă atât prin ideile transmise prin intermediul cuvintelor, cât și prin emoție. Persuasiunea are la bază o serie de factori: „,simplitatea, perceperea interesului propriu, încrederea și empatia. ${ }^{“ 41}$ Vin în completarea acestora trei elemente ce țin de procesarea cognitivă: „atenția, abordarea și afilierea.“42 Acești itemi sunt de luat în calcul ca puncte de referință în convingerea spectatorului.

În continuarea acestor secrete ale persuasiunii, Eusebiu Ștefănescu vine cu un sfat către artistul dramatic: „să fii tu convins pentru a convinge pe alții.“43 Această convingere își are rădăcinile în asumare. Pentru a transmite emoții, artistul apelează la inundarea altei lumi lăuntrice. De această dată, el trebuie să își asume o serie de trăiri. Această asumare va transmite în funcție de cât trăiește artistul.

Textul dramatic vine și de această dată ca sursă a identificării trăirilor specifice situației, relației și motivației în care se află personajul interpretat, de fapt, actorul care-i trăiește toate circumstanțele. Pe de altă parte, ,personajele sunt în noi“"44, la fel ca trăirile. Sigur că drumul mai scurt e cel de a apela la elemente specifice și recognoscibile ale trăirii redate prin modelarea mijloacelor de expresie. Aceasta poate să confere recunoaștere. Însă adevărata „bucurie a recunoașterii unei esențe cuprinde și recrearea operei.“45 Deci recunoașterea unei esențe poate deveni sursă de inspirație pentru un alt artist sau o schimbare de perspectivă în actul creator în opera în care se regăsește. Pe de altă parte, această esență controlează și conturează mijloacele de exprimare. Esența unei trăiri va da viață unui cuvânt sau gest însuflețit și expresiv.

41. Kevin Dutton, Arta manipulării, ed. cit., p. 11.

42. Ibidem, p. 109.

43. Eusebiu Ștefănescu, Retorica limbajului scenic, ed. cit., p. 71.

44. Ibidem, p. 17.

45. Ibidem, p. 46. 
Înțelegând contextul creat și adaptându-se unei alte realități, actorul își mobilează lumea lăuntrică și trăiește esența propusă. $\mathrm{Cu}$ ajutorul instrumentelor de exprimare, el reușește să contamineze spectatorul cu o emoție în funcție de capacitatea și puterea lui de exprimare. „Emoția în artă are un caracter spiritual, diferențiindu-se de sensul strict psihologic al contextului. Ea este fecundată de cultura și spiritul meditativ al consumatorului de frumos.“46 Iată că trăirea transformată în emoție nu este suficientă în artă. Mai mult decât atât, „dacă în elaborarea rolului actorul trebuie să fugă întâi de realitate pentru a-și atinge starea de grație, de inspirație creatoare de viziuni, trebuie apoi să-și transpună viziunile în realitate pentru a fi reale și vii, unice și irepetabile. “" Așa cum „la modul ideal, cuvântul actorului trebuie să fie edificator, având energia insuflată prin dicteu divin“44, actorul se conectează la o anumită energie de unde își ia seva inspirației.

În transferul trăirii lăuntrice a actorului spre emoția care să invadeze spectatorul, cuvântul joacă un rol esențial prin „forța emoțională a sunetului care îi adaugă acuitate afectivă.“" Și: „Transformând informația naturală într-una culturală, vorbirea nu comunică nici percepții, nici emoții, ci denotația și conotația semnificațiilor verbale în care s-au cristalizat trăirile senzorial-afective. ${ }^{\text {“50 }}$ Mai mult decât atât, arta 1̂și propune o altă abordare a emoției: „expresie a emoțiilor umane, nu manifestarea lor naturală, arta nu comunică însăși emoția, ci conotația în care emoția s-a transformat alături de denotația semnificațiilor verbale. Numai emoția declanșată de expresia atitudinii umane față de lume este estetică. În opoziție cu cea naturală, cea estetică este cultă, adică trecută prin vorbirea creatorului, cât și prin vorbirea publicului.“51

46. Ion Toboșaru, Principii generale de estetică, ed. cit., p. 250.

47. Eusebiu Ștefănescu, Retorica limbajului scenic, ed. cit., p. 31.

48. Ibidem, p. 59.

49. Henri Wald, Puterea cuvântului, ed. cit., p.73.

50. Ibidem, p. 7.

51. Ibidem, p. 11. 
Dincolo de puterea emoțională pe care o deține prin sonoritate, cuvântul capătă o culoare, o nuanță afectivă, acesta devenind un element exterior care devine consistent, o aparență care capătă esență. Această esență la care s-a ajuns prin asumarea unei trăiri conduce spre ideea de suflet al cuvântului, de cuvânt care devine mai mult decât un cumul de sunete sau un deținător de sens. Emoția artistului se transpune în acest fel și capătă o formă stilizată: ,,Arta nu transmite însăși emoția creatorului, ci conotația în care s-a cristalizat emoția prin intermediul vorbirii. Emoția estetică este organizată - sensibilizează un înțeles în cadrul spațial sau temporal determinat al unei opere, socială - se adresează celorlalți, comunității și reiterativă - poate fi repetată.“52

\section{Interdependența idee-emoție}

„Arta lipsește când ideile nu sunt trăite, dar și când trăirile nu sunt gândite. ${ }^{\text {"53 }}$ Am abordat trei etape distincte în vederea asumării unui text, a unor idei și a unor trăiri. Contopirea acestora duce la crearea unui nucleu complet și complex care își va întrebuința încărcătura în valorificarea și nuanțarea mijloacelor de exprimare. Nu putem omite faptul că acest instrument, cuvântul, nu capătă valoare și mai consistentă în clipa în care este însoțit de gest, atitudine corporală, mimică. Armonia și echilibrul dintre aceste arme ale artistului dramatic conturează, într-un discurs și mai credibil, mesajul și emoția. „Chiar în rugăciunile tăcute, cuvintele trebuie rostite în gând cu claritate, iar atitudinea corpului e cea care conferă putere cuvântului.“" ${ }^{54}$ Întregul arsenal are același scop: transmiterea ideii și a emoției, și împreună au forță mai mare de a convinge. „Cuvântul susținut de gest are o încărcătură magico-religioasă și se bucură de o eficacitate care susține forța magică a limbajului scenic. “" ${ }^{55}$ Eficiența acestor mijloace, după cum menționam mai sus, se dovedește și în

52. Ibidem, p. 49

53. Henri Wald, Puterea cuvântului, ed. cit., p. 50.

54. Eusebiu Ștefănescu, Retorica limbajului scenic, ed. cit., p. 7.

55. Ibidem, p. 8. 
cazul tăcerii pe scenă, tăcere pe care nu trebuie să o confundăm cu pauza logică, ci să o asemănăm cu pauza psihologică. Aceste momente de tăcere și nu de liniște au un efect uriaș pe scenă, tocmai pentru că transmit enorm, bucurându-se de o sărăcie de mijloace. Este, de fapt, o vorbire nerostită, o tăcere care vorbește prin intermediul gândului viu. Ca în rugăciune, tăcerea din teatru nu este niciodată pasivă, ci „o tăcere încărcată de energia cuvintelor nerostite, tăcere grăitoare, plină de expresivitate. “" ${ }^{66}$ „Vorbirea se opune tăcerii, rostirea se opune și liniștii.“"57

Idealul cuvântului rostit de actor pe scenă este identificat de Peter Brook: atunci când interpretul rostește cuvântul „noapte“ se face întuneric. Magia acestui cuvânt rostit poate să fascineze și să cucerească spectatorul. Totodată, magia aceasta e permisă de faptul că, odată „,rostit, el atrage realul, îl edifică. “58 „Dimensiunea semantică a cuvântului se numește idee în opoziție cu realul, semnificație în opoziție cu semnificantul, sens în opoziție cu referentul, gând în opoziție cu acțiunea, înțeles în opoziție cu experiența.“" ${ }^{59}$ Astfel, „spectacolul teatral arată în patru dimensiuni ceea ce textul nu poate sugera decât într-una singură."60

$\mathrm{Nu}$ este suficient dacă prin intermediul cuvântului se transmit strict idei. Ne adresăm doar părții raționale printr-o serie de idei reci. De asemenea, nici contaminarea strict cu emoție nu este una convingătoare, deoarece este lipsită de logică. Ideea devine mai puternică și are un alt impact când este însoțită de emoție: în consecință, emoția capătă sens. Astfel, ,arta creează un semnificant care, prin simbolizare, realizează unitatea dintre rațiune și sensibilitate“61 și trimite idei emoționante. În această perspectivă, cuvântul are rolul de a stârni universul lăuntric al spectatorului, ținând cont atât de

56. Ibidem.

57. Henri Wald, Puterea cuvântului, ed. cit., p. 42.

58. Eusebiu Ștefănescu, Retorica limbajului scenic, ed. cit., p. 9.

59. Henri Wald, Puterea cuvântului, ed. cit., p. 89.

60. Ibidem, p. 108.

61. Henri Wald, Puterea cuvântului, ed. cit., p. 104. 
afirmația că „de la teatru se pleacă discutând“"62, cât și de cea care îi conferă artei sarcina de „a impresiona și a emoționa.“63

Descifrarea textului, delimitarea frazelor, conturarea ideilor, însușirea trăirii sub influența contextului sunt pașii care conduc spre descoperirea gândului și sufletului cuvântului. Alături de trupul cuvântului, care este reprezentația sonoră a acestuia, $a$ gândului și a sufletului acestuia, logosul rostit pe scenă ișsi dobândește forma completă, ideală. De cele mai multe ori, actorul caută forma care să transmită. Această formă vine din acele lumi lăuntrice identificate și asumate. Cuvântul trebuie să intre în contact cu realul atunci când există un preaplin de gând și trăire. El vine ca mijloc de a exprima interiorizarea. Doar astfel, ajuns la urechile spectatorului, el poate să parcurgă drumul invers și să stârnească un gând, o vorbire nerostită, și o emoție cu care acesta să rezoneze. Tendința actorilor tineri merge spre firesc și simplitate. Riscul este în imediata vecinătate, deoarece banalul seamănă cu acest firesc. Banalul își are rădăcinile în vorbirea cotidiană, iar „banalizarea întărește denotația în dauna conotației.“64 Această tendință vine dintr-o frică de a nu bate pe cuvânt, de a nu colora, nuanța exagerat. În frica de a nu cădea în această extremă, preferă extrema cealaltă. Pentru a găsi un echilibru, trebuie descoperit de fiecare dată din interior spre exterior, de la esență spre aparență. Destinația acestui traseu de mobilare și mobilizare a interiorului îi va aduce actorului rezultatele dorite și va demonstra, de cele mai multe ori, surpriza călătoriei, cea a descoperirii mai savuroasă și ofertantă decât însăși destinația. Nu trebuie să eludăm în emiterea cuvântului pe scenă elocința, care este „sunetul ce face o inimă pasionată.“65

În evitarea acestei capcane întinse de banalul vorbirii cotidiene, cuvântul trebuie privit atât prin prisma denotației, cât și a conotației. „Prin limbaj, percepția devine denotație și emoția se transformă în conotație. “66 $\mathrm{Cu}$ cât denotația

62. Ibidem, p. 78.

63. Ibidem, p. 32.

64. Ibidem, p. 113.

65. Mircea Frânculescu, Retorica românească. Antologie, București, Editura Minerva, 1980, p. 245.

66. Henri Wald, Puterea cuvântului, ed. cit., p. 104. 
cuvântului este mai generală, cu atât mai mult se poate forja în profunzimea conotației acestuia.

„Actorul trăiește o situație fictivă, dar convertită în realitatea concretă, credibilă, adevărată." ${ }^{67}$ Cuvântul rostit va face parte din această realitate. Iată, în cele din urmă, cum actorul însuflețește cuvântul scris spre a deveni unul concret, credibil și adevărat. În funcție de nivelul de asumare a noii realități, a situației date, a făuririi unei idei și a trăirii cu credință, actorul le va da credință și, consecutiv, și cuvântul va mișca.

Pentru că vorbim de artă și artist, nu putem să nu aducem în discuție ceea ce vine și dă sclipire unui algoritm, unui raționament, unei metode: talentul, „capacitatea de a transforma experiența în expresie, de a exprima experiența senzorială, afectivă și pragmatică într-un sistem de semne.“68 Există „o tensiune creatoare dintre individualitatea experienței și sociabilitatea expresiei menită mai puțin să comunice fiecăruia ceea ce știe toată lumea și mai mult să comunice tuturor ceea ce a înțeles fiecare. “69 Dincolo de experiența fictivă pe care o trăiește, actorul apelează la bagajul său de experiențe personale pentru a putea acoperi afectiv. Memoria afectivă este sertarul la care artistul apelează pentru a se putea conecta și mai profund și adevărat cu trăirea situației fictive. Însă, „în istoria limbajului, memoria înseamnă uitarea semnificațiilor timpurii și particulare și amintirea semnificațiilor mai recente și mai generale. ${ }^{" 70}$

Plecând de la premisa că „teatrul țintește să realizeze un echilibru între trăire și gândire“"71, actorul trebuie să atingă performanța deținerii unui cuvânt autentic care are gând și care are puterea de a emoționa, înglobând condiția actorului cuprinsă în versuri de Nichita Stănescu: „Eu nu cuvinte-ți spun, ci lacrimi. ${ }^{“ 72}$

67. Eusebiu Ștefănescu, Retorica limbajului scenic, ed. cit., p. 86.

68. Henri Wald, Puterea cuvântului, ed. cit., p. 58.

69. Ibidem, p. 67.

70. Ibidem, p. 97.

7I. Ibidem, p. 80.

72. Apud Eusebiu Ștefănescu, Retorica limbajului scenic, ed. cit., p. 23. 


\section{Energia}

Regizorul Andrei Șerban susține că ,,nu există o expresie mai vie a vieții decât cuvântul, deoarece vocea (canalul din care cuvintele prind viață) este o manifestare expresivă a respirației, iar respirația înseamnă viață în sine.“73 Analizând doar procesul de formarea a sunetului, a cuvântului, putem observa cum cuvântul înseamnă, de fapt, viu, viață.

Dincolo de mesajul și emoția pe care își propune să le transmită, cuvântul are o energie specifică care realizează conexiuni între indivizi: „Puterea logosului este imensă: el aduce plăcere, alungă grijile, fascinează, convinge, transformă cu ajutorul farmecului. "“74

Dincolo de cuvântul expresiv, el deține o putere, o forță care stârnește în ascultător mai mult decât atenția. Conexiunea pe care o realizează între lumea lăuntrică a indivizilor îi conferă o valoare dincolo de conținutul pe care îl exprimă. Această energie este contopită în începuturile umanității și ale verbului divin: „La început a fost Cuvântul.“

Energia cuvântului rostit poate fi considerată una de natură magică, tocmai prin asemănarea cu originea sa: „energia pe care o regăsim în cuvintele sacre, în rugăciune, în blestem, în descântec. În cuvântul încărcat de energie, în cuvântul izvorât de logos, în cuvântul de început (logosul divin) stă puterea magică a cuvântului care, prin har, devine vestitor sau poet sau șaman-vindecător de suflete." 75

Această energie nu trebuie confundată cu o agitație interioară care se manifestă, de cele mai multe ori, pe scenă printr-o precipitare a cuvintelor, a gesturilor, a acțiunilor. Discutam mai sus despre o conectare la energia divină, cosmică pentru a căpăta inspirația creatoare. Energia cuvântului rostit este conectată la aceeași energie, fiind însăși viață. Totodată, ,,există un câmp magnetic al cuvintelor, o tensiune a energiei lor sonore și de sens ${ }^{\text {“76 }}$, o interdependență între forma sonoră și esență.

73. https://www.youtube.com/watch?v=ZkExNbsj7lg, consultat la 27.09.2020, 04:21.

74. Eusebiu Ștefănescu, Retorica limbajului scenic, ed. cit., p. 27.

75. Ibidem, p. 24.

76. Ibidem, p. 81. 
Transferul de energie între actor și spectator ține de „grija actorului ca fiecare cuvânt, fiecare gest să fie de o expresivitate maximă, așa încât să nu cadă în fosă, ci să aibă importanță și să transmită energie.."77

\section{Empatia}

Publicul de teatru este ,o colectivitate de individualități gânditoare și apreciatoare. Visezi singur, dar râzi împreună cu alții. “"78 Pe de altă parte, ,,spectatorii sunt oameni diferiți. Ei devin public numai atunci când se contaminează de o stare, de o emoție, de un gând." ${ }^{\text {"79 }}$

Între actorul emițător și spectatorul receptor se realizează o conexiune spirituală, emoțională, în teatru regăsindu-se și „principiul inimilor comunicante“"80. Sigur că spectatorul nu intră în conexiune doar cu artistul dramatic, ci și cu ideile, frământările, emoțiile celorlalți artiști care au conceput creația teatrală.

Ca un efect al eficienței și productivității ce îl propagă o transmitere, o contaminare, o emitere eficientă din partea artistului, spectatorul răspunde prin însăși implicarea sa emotivă și se realizează, astfel, transferul de la conceptul de spectator la cel de public. Artistul transmite pornind din universul său lăuntric spre universul lăuntric al spectatorului. Această comunicare se realizează prin elemente de exprimare ale limbajului artistic și ajunge la nivelul de conectare spirituală. Conexiunea între interioarele indivizilor invită prin înțelegere, sensibilizare și rezonanță la implicare. Cu alte cuvinte, artistul primește în mod real o confirmare a ceea ce inițiază și emite, iar spectatorul se apropie de catharsis.

Teatrul pune față în față oameni care dau credibilitate prin convenție unei alte realități, o ficțiune persuasivă de care actorul trebuie să fie convins, astfel încât spectatorul să treacă de convingere și să atingă punctul în care devine

77. Ibidem, p. 32.

78. Henri Wald, Puterea cuvântului, ed. cit., p. 82.

79. Eusebiu Ștefănescu, Retorica limbajului scenic, ed. cit., p. 31.

80. Ibidem. 
participant pasiv al acestei ficțiuni create spre a fi percepută, dar și pricepută. „Ceea ce se percepe este imitativ, iar ceea ce se pricepe este o atitudine pragmatic-afectivă, sensibilul mimează realul, iar inteligibilul ia atitudine față de el."81

Asemenea actorului, spectatorul se bucură de unicitate prin definirea lui ca individualitate. Așa cum artistul pune în joc bagajul său rațional, emoțional și spiritual pentru a-și concepe și contura expresia, spectatorul decodează și rezonează în funcție de propriile înmagazinări lăuntrice. Prin prisma acestora, el are reacții asupra expresiilor artistice care se conectează cu experiențele sale unice și susține acea participare, fie ea pasivă sau chiar activă, atunci când lumea sa lăuntrică răspunde prin elemente ce țin de exprimare: plâns, râs, aplauze.

În cazul receptării, se pot identifica diferențe, chiar dacă ceea ce actorul îndeplinește este considerat general valabil: „receptarea artei nu se consumă uniform, ci diferențiat, în funcție de cultură, de temperament, de sensibilitatea publicului, iar orientarea ideologică, criteriul de clasă al aprecierii, ocupă un rol important. Se pare că fiecare vârstă descifrează noi sensuri în cercul operei și își concretizează atenția în legătură cu creația literar-artistică din unghiuri diferite. Adolescentul va reține din Romeo și Julieta tragedia iubirii, tânărul va fi ispitit de specificul epocii Renașterii, asociind timpul cu destinul uman, urmând ca, în faza maturității intelectuale, opera să se răsfrângă pe liniile ierarhizărilor, a comparațiilor, a unor judecăți de valoare solide." ${ }^{\text {"82 }}$

Totuși, dincolo de tot ceea ce definește individualitatea acestui spectator, el trebuie să fie contaminat pentru a introduce în actul de recepție această participare afectivă. Calitatea spectatorului de implicare și reacție este definită de empatie, această „capacitate a unui subiect de a disimula, de a intra în pielea altuia, de a se transpune simpatetic și este declanșată de o emoție estetică. ${ }^{\text {(83 }} \mathrm{Cu}$ alte cuvinte, participarea publicului împlinește întreaga creație scenică, o ridică la rang superior, spectatorii trăind catharsisul.

81. Henri Wald, Puterea cuvântului, ed. cit., p. 10.

82. Ion Toboșaru, Principii generale de estetică, ed. cit., p. 251.

83. Eusebiu Ștefănescu, Retorica limbajului scenic, ed. cit., p. 84. 


\section{Poezia}

Dacă, prin transferul din planul scris în cel al rostirii care se agață de real, cuvântul capătă oralitate, întregul limbaj se cristalizează sub amprenta oralității, iar „toate celelalte mijloace de exprimare traduc oralitatea." ${ }^{44}$

Poezia poate fi privită în această căutare continuă a șlefuirii mijloacelor de exprimare și a lumii lăuntrice drept un instrument ce produce progrese tocmai prin dificultatea și complexitatea pe care o propune. Ea invită spre o formă atipică și inconfortabilă, de cele mai multe ori, față de vorbirea cotidiană, dar și spre un univers variat, amplu de semnificații care va nuanța, va inunda lumea interioară a artistului emițător. Cuvântul scris este regăsit în poezie sub formă de esențe, esențe ce se vor cristaliza în primă instanță în gânduri, frământări, trăiri în interiorul actorului, apoi în fascicule de gând și particule de emoție. De asemenea, ea reprezintă un reper în definirea oralității, aceasta fiind, de fapt, „condiția originară a poeziei." ${ }^{\text {" } 5}$

Plecând de la text ca materie primă în delimitarea și decodarea frazelor și a ideilor, artistul trebuie să depășească ideea de recitare a poeziei și să ajungă la nivelul de interpretare convingător, simplu, frumos și firesc. Textul poetic cucerește inițial prin forma care îi conferă muzicalitate. Precum un cuvânt ce rămâne în stadiul de pronunție frumoasă, poezia poate păcăli actorul prin această aparență. Doar că spectatorul nu va putea fi păcălit, pentru că nu va primi nici mesaj, nici emoție, ci doar o înșiruire plăcută auzului, dar care nu stimulează rațiunea și nu mișcă sufletul. Secretul stă în a prefera fondul în detrimentul formei, păstrând, desigur, misterul și izul unic al acestei creații poetice. De exemplu, dacă actorul respectă rima și plasează o pauză logică după fiecare vers, va distruge fraza, respectiv ideea. Totodată, semnele de punctuație scrisă trebuie adaptate în funcție de intenția pe care o va dobândi fraza. O virgulă, de asemenea, poate destrăma firul logic al unei idei, idee care nu îi aparține

84. Ibidem, p. 41.

85. Ibidem, p. 7. 
actorului, ci poetului. Astfel, actorul riscă să rămână „prizonierul muzicalității și al locului comun." ${ }^{\text {86 }}$

Actorul va folosi cuvântul ca generator de sens și sensibilitate și va ajunge la esența cuvântului care are puterea de a trece de la frază la gând, la idee și emoție. Plecând de la elementele-cheie în însuflețirea cuvântului rostit, actorul va îngloba în cuvânt atât esența, cât și forma acestuia. Datorită semnificațiilor, conotațiilor multiple care formează trupul poeziei, se simte nevoia completării acestor asumări noi ale unor cuvinte scrise, ale unei alte gândiri și trăiri. Această magie a poeziei solicită măiestrie în rostirea cuvântului pe scenă și propune o muncă a artistului cu textul poetic mult mai amănunțită și elaborată.

Fiecare poet poate fi recognoscibil și mai ușor descifrabil prin acordarea unui stil. Stilul poate clarifica intențiile creatoare și poate veni în ajutorul celui care dorește să elibereze textul poetic din lumea scrisului. Poate aduce clarificări cu privire la descifrarea textului în dorința de a făuri idei. De asemenea, poetul capătă unicitate printr-un ,anumit stil pentru a exprima nu numai ce a aflat despre realitate, dar și atitudinea pe care o ia față de realitate.“87 Altfel spus, „selectarea anumitor cuvinte și combinarea lor în sintagme noi, potrivit proprietăților prozodice și stilistice îngăduie poetului să comunice, pe măsura talentului său, o parte cât mai mare din emoțiile pe care i le provoacă lumea în care trăiește." 88

Dacă, în cazul unui text dramatic, prezentam ca reper o aplecare spre documentarea operei dramatice, în întâlnirea cu creația poetică actorul realizează o conexiune mai puternică între el și creator, „trăind starea de grație a poetului, ca și cum i s-ar substitui prin empatie." " 99 În laboratorul său lăuntric, actorul trebuie să se contamineze prin empatie cu această stare de grație care a fost izvor primordial și esențial în conceperea textului poetic. Este cât se poate de clar, ,în interpretarea poeziei trebuie să intri în pielea poetului, să-ți asumi jertfa lui de suflet.“90

86. Eusebiu Ștefănescu, Retorica limbajului scenic, ed. cit., p. 83.

87. Henri Wald, Puterea cuvântului, ed. cit., p. 21.

88. Ibidem.

89. Eusebiu Ștefănescu, Retorica limbajului scenic, ed. cit., p. 76.

90. Ibidem. 
Precum teatrul, poezia propune înfăptuirea unei alte realități, atenția și concentrarea interpretului fiind orientată „,asupra viziunii poetice ca să-și însușească starea, tensiunea, energia puse la bătaie pentru a crea o altă realitate utopică, irealizabilă în parametrii normalității. " ${ }^{\text {"1 }}$

Pe de altă parte, poezia poate fi considerată o formă de comunicare. Am putea spune, la fel ca în cazul textului dramatic, că ea trebuie să ajungă la gândul și sufletul celui ce o receptează. Fiind „forma cea mai subtilă de comunicare cu divinitatea și a oamenilor între ei ${ }^{\text {“92, }}$, poezia îl invită pe actor „să retrăiască nu o stare, nu o situație ca în teatru, ci să retrăiască o transă,"993 tinzând spre „revelația trecerii pe o treaptă superioară a exprimării poetice." ${ }^{\text {(94 }}$

În dorința de a atinge aceste nuanțe interpretative superioare pe care le solicită poezia, cuvântul capătă și el puterea și esența lui originară. Astfel, actorul își asumă cuvintele poetului, ,care nu sunt purtătoare de semnificații, sunt purtătoare de energii; ele nu comunică, ci edifică; nu exprimă realul, ci îl atrag." "95 Așadar, energia cuvântului rostit pe scenă este cea pe care și-o propune poezia, acest instrument al actorului de a se perfecționa, de a căuta dincolo de formă și aparență.

Sigur că, prin intermediul vorbirii, cuvintele cuprinse în poezie vor dezvolta idei. Însă, acest cuvânt este „cuvânt de sine stătător, nu doar purtător de semnificații și participă la actul numirii.“96

Multitudinea de trimiteri, esențe, conotații conferă o perspectivă emancipată a limbajului care poate deveni sursă de inspirație, energie și esență în abordarea limbajului scenic. Ceea ce oferă particularitate acestui limbaj poetic ține de faptul că el „transmite un mesaj cu cel puțin două niveluri: cognitiv, care este suma conținuturilor semnelor dublu

91. Ibidem, p. 81.

92. Ibidem.

93. Ibidem.

94. Ibidem.

95. Ibidem, p. 76.

96. Ibidem, p. 81. 
articulate și a faptelor de sintaxă care le leagă și simbolic, care este acela al valorilor adăugate lingvistic articulat. ${ }^{697}$

\section{Concluzie}

Cuvântul scris este sursă de inspirație și energie în aprofundarea gândului și a sufletului cuvântului. Pornind de la suma cuvintelor cuprinse în textul dramatic, observăm necesitatea unei asumări a textului, a frazei care devine idee și a trăirii care devine emoție. Cuvântul rostit trebuie să capete calitatea de a parcurge drumul invers atunci când îl contaminează pe spectator. De această dată, un element al limbajului extern produce rezonanță în limbajul intern al privitorului. Conexiunea dintre gând și trăire oferă ideii capacitatea de a nu fi strict sens, ci o idee care pătrunde în rațiunea publicului și în inima acestuia. Pe lângă aceste două aspecte ce întregesc cuvântul rostit, energia logosului de la Început este cea care străbate câmpul magnetic al ascultătorului. Idealul în actul de creație tinde spre starea de purificare a publicului, care se poate trăi doar prin empatie. Blocajele care apar în timpul creației pot fi depășite prin întoarcerea la esența cuvântului scris, iar nu prin abordarea strictă a formei cuvântului, care rămâne la nivel de plăcere auditivă și care nu vine ca o consecință ce ar încununa doar lumea lăuntrică a gândirii, ci și lumea lăuntrică a trăirilor interpretului. Atunci când acest cuvânt cucerește lumile lăuntrice ale spectatorului care participă afectiv, prin empatie, la actul artistic, el depășește ideea de sunet și stârnește gândul și trăirea spectatorului.

\section{Bibliografie:}

Benveniste, Emile, Problèmes de linguistique générale, Paris, Éditions Gallimard, 1966.

CovăTARIU, Valeria, Cuvânt despre cuvânt, Târgu Mureș, Editura Casa de editură Mureș, 1996.

97. Bertil Malmberg, Signes et symboles, Paris, Éditions Picard, 1977, p. 257. 
Detienne, Marcel, Stăpânitorii de adevăr în Grecia Antică, Editura Symposion, 1996.

DuTTON, Kevin, Arta manipulării, București, Editura Globo, 2019.

FrÂnculescu, Mircea, Retorica românească. Antologie, București, Editura Minerva, 1980.

Malmberg, Bertil, Signes et symboles, Paris, Editura Picard, 1977.

MoISESCU, Vasile, Lectura artistică și recitarea, București, Editura

Comitetul de stat pentru cultură și artă. Casa centrală a creației populare, 1967.

ToBoșARU, Ion, Principii generale de estetică, Cluj-Napoca, Editura Dacia, 1978.

WALD, Henri, Ideea vine vorbind, București, Editura Cartea Românească, 1983.

WALD, Henri, Puterea vorbirii, București, Editura Științifică și Enciclopedică, 1981.

WALD, Henri, Realitate și limbaj, București, Editura Academiei republicii socialiste, 1968.

ZARIFOPOL, Paul, Pentru arta literară, vol. I, București, Editura Minerva, 1971. 